\title{
Analisis Pengelolaan Dana Tabarru (Asuransi Jiwa Syariah) dalam Produk Pembiyaaan di BMT Mardhatillah Berkah Karawang
}

\author{
Dodi Hermawan $^{1}$, Asep Dede Kurnia ${ }^{2}$, M. Cahyo Sucipto ${ }^{3}$ \\ ${ }^{1}$ KSPPS Mardhotillah Berkah \\ ${ }^{2,3}$ STIES Indonesia Purwakarta \\ Jln. Veteran no 150-152 Purwakarta 41113 Jawa Barat INDONESIA \\ 1dodi06mei@gmail.com \\ 2asepdedekurnia@gmail.com \\ ${ }^{3}$ cahyosucipto@gmail.com
}

Abstrak - Lembaga keuangan Syariah non bank seperti BMT harus bisa melakukan sistem manajemen resiko pembiayaan yang baik agar resiko yang terjadi dapat diminimalisir, adapun upaya yang dilakukan oleh pihak BMT Mardhatillah Berkah Karawang dalam meminimalisirnya dengan cara membebankan pada setiap anggota yang melakukan Pembiayaan dengan membayar dana Tabarru dan itu di bayarkan sekali saja pada saat anggota melakukan pencairan pembiayaan. Tujuan dari penelitian ini adalah untuk mengetahui pengelolaan dana Tabarru dalam Produk Pembiayaan di BMT Mardhatillah Berkah dan untuk mengetahui Penerapan akad Tabarru yang dilakukan pada saaat pembiayaan. Tabarru' dapat diartikan seperti sumbangan, hibah, dana kebajikan, atau derma. Sedangkan orang yang memberikan sumbangan disebut dengan mutabarri' atau dermawan. Berdasarkan hasil penelitian setiap anggota yang melakukan Pembiayaan di BMT, Baik itu Pembiayaan Murabahah, Mudharabah, Dan Rahn, akan ada Dana Tabarru yang harus dibayarkan pada saat Pencairan Pembiayaan dimana dana Tabarru ini akan digunakan untuk saling membantu atau saling menanggung apabila ada resiko meninggal dunia diantara anggota BMT. Dalam akad Tabarru', Anggota memberikan hibah yang akan digunakan untuk menolong Anggota BMT lainnya yang mengalami musibah atau kejadian diluar kehendak manusia, sehingga dana tersebut dipisahkan dengan dana lainnya.

Kata Kunci : Pengelolaan, Tabarru, Penerapan, akad

Abstract - Non-bank Islamic financial institutions such as BMT must be able to conduct a good financing risk management system so that the risks that occur can be minimized, while the efforts made by BMT Mardhatillah Berkah Karawang in minimizing it by charging each member who is doing Financing by paying Tabarru funds and that paid only once when members make funding disbursements. The purpose of this study is to determine the management of Tabarru funds in Financing Products at BMT Mardhatillah Berkah and to determine the implementation of the Tabarru contract which was carried out at the time of financing. Tabarru 'can be interpreted as donations, grants, benevolent funds, or alms. Whereas those who make donations are called mutabarri or generous. Based on the research results of each member who conducts Financing at BMT, Be it Murabahah, Mudharabah, and Rahn Financing, there will be Tabarru Funds that must be paid at the time of Funding Disbursement where Tabarru funds will be used to help each other or bear one another if there is a risk of death among BMT members. In the Tabarru contract, the Member gives a grant which will be used to help other BMT Members who experience an accident or an event that is outside of human will, so that the funds are separated from other funds.

Key words : Management, Tabarru, Implementation, contract 


\section{PENDAhUluan}

Perkembangan lembaga keuangan Syariah di Indonesia dari tahun ke tahun mengalami peningkatan yang pesat, hal tersebut bisa kita lihat dengan banyaknya lembaga-lembaga keuangan yang berdiri baik lembaga bank maupun non bank misalnya seperti asuransi Syariah, koperasi Syariah maupun Baitul Mal Wat Tamwil (BMT). Peran umum BMT yang dilakukan yaitu melakukan pembinaan dan pendanaan yang berdasarkan prinsip syaraiah. Peran ini menegaskanarti penti prinsip-prinsip Syariah dalam kehidupan ekonomi yang di lakukan masyarakat apalagai kita mayoritas muslim. Sebagai lembaga keuangan Syariah yang bersentuhan langsung dengan masyarakat kecil yang serba cukup ilmu pengetahuan atau pun materi tentatng apa itu BMT, Lembaga seperti BMT mempunyai tugas penting dalam mengemban misi keislaman dalam aspek kehidupan masyarakat terutama ekonomi islam.

Lembaga keuangan Syariah non bank seperti BMT harus bisa melakukan sistem manajemen resiko pembiayaan yang baik agar resiko yang terjadi dapat diminimalisir, adapun upaya yang dilakukan oleh pihak BMT Mardhatillah Berkah Karawang dalam meminimalisirnya dengan cara membebankan pada setiap anggota yang melakukan Pembiayaan dengan membayar dana Tabarru dan itu di bayarkan sekali saja pada saat anggota melakukan pencairan pembiayaan. Ketika anggota membayar dana Tabarru pihak BMT tidak mengelolanya secara langsung, melainkan bekerjasama dengan perusahaan asuransi Syariah. Perusahaan - perusahaan jasa asuransi Syariah termasuk sarana penting yang di rujuk lembaga BMT untuk melindungi dan menjamin keamanan diri anggota yang melakukan pembiayaan pada BMT dari berbagai resiko atau bahaya yang mengancam jiwa anggota yang melakukan pembiayaan (Syahatah, 2006).

Anggota yang melakukan Pembiayaan pada BMT akan merasa tenang jika di kemudian hari ada hal-hal yang tidak di inginkan oleh anggota, dan secara otomatis jika anggota masih memiliki kewajiban pada pihak BMT maka sisa kewajibannya mampu di klaimkan pada pihak Asuransi yang bekerja sama dengan Pihak BMT, dan tidak akan membebankan ahli waris.(Tanjung, 2015).

Melihat fenomena masyarakat yang demikian tentu menggugah hati sebagian orang yang peduli akan rasa kemanusiaan untuk kembali memupuk semangat rasa tolong-menolong. Sebagaimana yang tercatat dalam dinas kependudukan bahwa mayoritas penduduk Indonesia adalah beragama islam. Islam sangat menganjurkan umatnya untuk saling membantu dalam kebaikan dan tidak membantu dalam perbuatan kejahatan. Tolong menolong (ta'awun) sangat dianjurkan di dalam Islam.

A. Pengertian Asuransi Syariah

Asuransi atau pertanggungan adalah perjanjian antara dua pihak atau lebih, dimana pihak penanggung mengikatkan diri kepada tertanggung dengan menerima premi asuransi untuk memberikan pengganian kepada tertanggung karena kerugian, kerusakan atau kehilangan keuntungan yang diharapkan atau tanggung jawab hokum terhadap pihak ketiga yang mungkin akan diderita tertanggung yang timbul dari suatu peristiwa yang tidak pasti atau untuk mermberikan seseorang yang dipertanggungkan (Buchari, 2009).

Adapun menurut Undang-undang nomor 40 tahun 2014 tentang Perasuransian yang mana pengganti Undang-undang nomor 2 tahun 1992 tentang Perasiransian, Asuransi adalah perjanjian antara dua pihak, yaitu perusahaan asuransi dan pemegang polis, yang menjadi dasar bagi penerimaan premi oleh perusahaan asuransi sebagai imbalan (Sula, 2004).

B. Pengertian Dana Tabarru

Tabarru' berasal dari kata tabarra'ayatabarra' $u$, yang mempunyai arti sumbangan, hibah, dana kebajikan, atau derma. Sedangkan orang yang memberikan sumbangan disebut dengan mutabarri' atau dermawan. Tabarru' sendiri merupakan pemberian sukarela seseorang kepada orang lain, tanpa ganti rugi yang mengakibatkan berpindahnya kepemilikan harta itu dari pemberi kepada 
orang yang diberi (Sula, 2004).

Tabarru' secara hukum fiqhiyah masuk dalam kategori hibah. Salah satu definisi hibah dalam fiqh Al-Muamalat, Al-Shakr dikatakan bahwa pengertian umum hibah adalah berderma/ berTabarru' dengan harta untuk kemaslahatan orang lain dalam kondisi hidup (Sula, 2004). Apabila kita berderma maka kita tidak boleh mengharapkan imbalan terhadap sesuatu yang telah kita kerjakan.

Dana Tabarru' terdiri dari kata dana dan Tabarru'. Dalam kamus Bahasa Indonesia kata dana adalah uang yang disediakan atau sengaja dikumpulkan untuk suatu maksud, derma, sedekah, pemberian atau hadiah. Sedangkan Tabarru' artinya sumbangan hibah, dana kebajikan, atau derma. Dalam arti luasnya Tabarru' merupakan pemberian harta atau manfaat kepada orang lain baik langsung atau dimasa yang akan datang tanpa mengharap imbalan.

C. Pengertian Baitul Malwattamwil

Baitul Mal Wa Tamwil Adalah lembaga usaha mandiri terpadu yang isinya berintikan bayt al-mal wa at-tamwil dengan kegiatan mengembangkan usaha-usaha produktif dan investasi dalam meningkatkan kualitas kegiatan ekonomi pengusaha kecil dengan mendorong menabung dan menunjang pembiayaan kegiatan ekonominya. Selain itu, BMT juga dapat menerima titipan zakat,infak, dan sedekah, serta menyalurkannya sesuai dengan dan amanatnya. BMT merupakan lembaga ekeonomi atau lembaga keuangan Syariah nonperbankan yang bersifat informal karena lembaga ini didirikan oleh Kelompok Swadaya Masyarakat (LSM) (Hasan, 2013).

D. Pengertian Pembiayaan

Pembiayaan adalah penyediaan uang atau tagihan yang dipersamakan dengan itu, berdasarkan persetujuan atau kesepakatan antara Bank dengan pihak lain yang mewajibkan pihak yang dibiayai untuk mengembalikan uang atau tagihan tersebut setelah jangka waktu tertentu dengan imbalan atau bagi hasil menurut Kasmir (Kasmir, 2002).
Menurut UU No. 10 tahun 1998 tentang perbankan menyatakan pembiayaan adalah penyediaan uang atau tagihan yang dipersamakan dengan itu berdasarkan persetujuan atau kesepakatan antara bank dengan pihak lain yang mewajibkan pihak yang dibiayai untuk mengembalikan uang atau tagihan tersebut setelah jangka waktu tertentu dengan imbalan atau bagi hasil.

\section{METODE PENELITIAN}

Jenis penelitian ini adalah penelitian lapangan (field research) yaitu penelitian yang objeknya mengenai gejala-gejala atau peristiwa-peristiwa yang terjadi pada kelompok masyarakat. Sehingga penelitian ini juga bisa disebut penelitian kasus atau study kasus (case study) dengan pendekatan deskriptif kualitatif (Arikunto, 2013).

Penelitian kualitatif yaitu penelitian yang menghasilkan prosedur analisis yang tidak menggunakan prosedur analisis statistik atau cara kuantifikasi lainnya. Jelas bahwa pengertian ini mempertentangkan penelitian kualitatif dengan penelitian yang bernuansa kuantitatif yaitu dengan menonjolkan bahwa usaha kuantifikasi apapun tidak perlu digunakan pada penelitian kualitatif.

Teknik pengumpulan data merupakan cara yang dilakukan peneliti untuk mengungkap atau menjaring informasi dari responden sesuai lingkup penelitian. Berikut ini ada beberapa teknik pengumpulan data:

\section{A. Wawancara}

Wawancara atau interviu (interview) merupakan salah satu bentuk teknik pengumpulan data yang banyak dilakukan dalam penelitian deskriptif kualitatif dan deskriptif kuantitatif. Dalam penelitian ini wawancara dilakukan dengan cara langsung baik secara struktur maupun bebas dengan pihak BMT Mardhatillah Berkah Karawang, dengan cara menganalisis pengelolaan dana Tabarru' dalam pembiayaan produk pembiayaan BMT Mardhatillah Berkah Karawang dengan keterangan kepada kepala keuangan atau administrasi kantor, dan para staf- staf dari BMT Mardhatillah Berkah 


\section{EKSISBANK Vol. 4 No. 1 Juni 2020}

Karawang. Teknik ini digunakan pada saat studi pendahuluan dan pada saat penelitian dilakukan. Adapun dua orang dari pengelola BMT Yang di ajak wawancara antara lain Manager dan staff Administrasi BMT Mardhatillah Berkah Karawang, serta satu orang keluarga anggota yang pernah melakukan klaim Tabarru.

B. Observasi

Observasi atau pengamatan merupakan suatu teknik atau cara mengumpulkan data dengan jalan mengadakan pengamatan terhadap kegiatan yang sedang berlangsung. Dalam penelitian ini, peneliti menggunakan observasi non partisipatif, yaitu pengamat tidak ikut serta dalam kegiatan, atau bisa juga disebut observasi pasif. Peneliti terjun langsung ke lokasi penelitian untuk memperoleh data dan informasi, mengenai Analisis pengelolaan dana Tabarru' dalam pembiayaan produk pembiayaan di BMT Mardhatillah Berkah Karawang. Peneliti melakaukan penelitian langsung di Kantor BMT Mardhatillah Berkah Karawang.

C. Dokumentasi

Dokumentasi yaitu catatan yang berkaitan atau berhubungan dengan apa yang akan penulis teliti. Penulis menggunakan sumber dokumentasi karena dalam melakukan penelitian penulis memerlukan sumber pendukung atau tambahan untuk memperkuat data pokok. Adapun di antara dokumentasi yang penulis lakukan diantaranya ;

1. Foto Kegiatan Akad Pembiayaan

2. Brosur BMT Mardhatillah Berkah Karawang

3. Sumber data adalah subjek dari mana asal data penelitian itu diperoleh. Dalam melakukan penelitian ini data-data yang diperlukan diperoleh dari dua sumber yaitu:

A. Data Primer

Data primer adalah data yang dikumpulkan dan diolah sendiri oleh suatu organisasi atau perorangan langsung dari objeknya. Pengumpulan data tersebut dilakukan secara khusus untuk mengatasi masalah riset yang sedang diteliti. Sumber primer dalam penelitian ini di dapat dari hasil wawancara yang dilakukan dengan Pengelola BMT Mardhatillah Berkah Karawang

\section{B. Data Sekunder}

Data sekunder adalah data yang diperoleh dalam bentuk yang sudah jadi, sudah dikumpulkan dan diolah oleh pihak lain, biasanya sudah dalam bentuk publikasi. Data semacam ini sudah dikumpulkan pihak lain untuk tujuan tertentu yang bukan untuk keperluan riset yang sedang dilakukan peneliti saat ini secara spesifik (Suryani \& Hendryadi, 2015). Sumber sekunder penelitian ini diperoleh dari data atau arsip buku-buku referensi, dan situs website.

Analisis data adalah proses mencari dan menyusun secara sistematis data yang diperoleh dari hasil wawancara, catatan lapangan, dan bahan-bahan lain, sehingga dapat mudah dipahami, dan temuannya dapat diinformasikan kepada orang lain (Sugiyono, 2016). Analisis data dalam penelitian kualitatif dilakukan sejak sebelum memasuki lapangan, selama di lapangan dan setelah selesai di lapangan. Aktivitas dalam analisis data, yaitu: data reduction, data display, dan conclusion drawing/verification (Sugiyono, 2016).

A. Data Reduksi (Data Reduction)

Menurut Milles dan Huberman, mereduksi data adalah merangkum, memilih hal-hal yang pokok, memfokuskan pada hal-hal yang penting, dicari tema dan polanya. Dengan demikian data yang telah direduksi akan memberikan gambaran yang lebih jelas, dan mempermudah peneliti untuk melakukan pengumpulan data selanjutnya dan mencarinya bila diperlukan sehingga disusun secara sistematis dan mudah dikendalikan.

B. Penyajian data (data display)

Setelah data direduksi maka langkah selanjutnya adalah mendisplaykan data yang dapat dilakukan dalam bentuk tabel, grafik, pictogram dan sejenisnya. Melalui penyajian data tersebut maka data terorganisasikan, tersusun dalam pola hubungan, sehingga akan semakin mudah dipahami dalam rangka memperoleh kesimpulan sebagai temuan penelitian.

C. Penarikan kesimpulan atau verifikasi

(conclusion drawing/verification)

Langkah ketiga dalam analisis data kualitatif menurut Miles dan Huberman adalah penarikan kesimpulan dan verifikasi. Kesimpulan awal yang dikemukakan masih bersifat sementara, dan akan berubah bila 


\section{EKSISBANK Vol. 4 No. 1 Juni 2020}

tidak ditemukan bukti-bukti yang kuat yang mendukung pada tahap pengumpulan data berikutnya. Tetapi apabila kesimpulan yang dikemukakakn pada tahap awal, didukung oleh bukti-bukti yang valid dan saat peneliti kembali ke lapangan mengumpulkan data, maka kesimpulan yang dikemukakan merupakan kesimpulan yang kredibel.

Keabasahan data dalam penelitian ini ditentukan dengan menggunakan kriteria kredibilitas. Untuk mendapatkan data yang relevan, maka peneliti melakukan pengecekan keabasahan data hasil penelitian dengan cara:

A. Perpanjangan Pengamatan

Dalam penelitian ini peneliti melakukan perpanjangan pengamatan, dengan kembali lagi ke lapangan untuk memastikan apakah data yang telah penulis peroleh sudah benar atau masih ada yang salah.

B. Ketekunan Pengamatan

Meningkatkan ketekunan berarti melakukan pengamatan secara lebih cermat dan berkesinambungan. Dengan cara tersebut maka kepastian data dan urutan peristiwa akan dapat direkam secara pasti dan sistematis (Sugiyono, 2016). Meningkatkan ketekunan itu ibarat kita mengecek soal- soal, atau makalah yang telah dikerjakan, apakah ada yang salah atau tidak. Dengan meningkatkan ketekunan itu, maka peneliti dapat melakukan pengecekan kembali apakah data yang telah ditemukan itu salah atau tidak. Demikian juga dengan meningkatkan ketekunan maka, peneliti dapat memberikan deskripsi data yang akurat dan sistematis tentang apa yang diamati (Sugiyono, 2017).

C. Triangulasi

Dalam penelitian ini menggunakan triangulasi sumber. Triangulasi sumber digunakan untuk pengecekan data tentang keabsahannya, membandingkan hasil wawancara dengan isi suatu dokumen dengan memanfaatkan berbagai sumber data informasi sebagai bahan pertimbangan. Dalam hal ini penulis membandingkan data hasil observasi dengan data hasil wawancara, dan juga membandingkan hasil wawancara dengan wawancara lainnya
III. HASIL DAN PEMBAHASAN

A. Analisis Pengelolaan Dana Tabarru dalam produk Pembiayaan di BMT Mardhatillah Berkah Karawan

Dalam pelaksanaan pembiayaan di BMT terdapat beberapa prosedur yang dilakukan BMT dalam melakukannya. Dari hasil wawancara dan observasi diperoleh prosedur sebagai berikut:

a. Anggota mengajukan pembiayaan terlebih dahulu kepada BMT Mardhatillah Berkah karawang mengenai kebutuhan yang diperlukan. Dengan memberikan fotocopy Kartu Tanda Penduduk (KTP) dan Kartu Keluarga Kepada Pihak BMT.

b. Pihak BMT Mardhatillah Berkah karawang melakukan analisis kebutuhan terhadap anggota tersebut, kemudian akan disesuaikan dengan Standart Operasional Prosedur yang ada di BMT Mardhatillah Berkah karawang, pengajuan Pembiayaan yang di ajukan oleh calon anggota.

c. BMT Mardhatillah Berkah karawang akan melakukan survey kepada anggota yang melakukan pengajuan. Survey inilah yang akan menentukan kualitas ataupun nanti di setujui atau tidaknya pembiayaan yang diajukan anggota.

d. Apabila pembiayaannya di acc atau di setujui, maka pihak dari BMT Mardhatillah Berkah karawang akan menghubungi anggota untuk mengkonfirmasi bahwa akan dilakasanakannya akad Pembiayaan, untuk akad pemb iayaan sendiri biasanya kondisional bisa dilakukan di Kantor BMT Mardhatillah Berkah Karawang atau di Rumah anggota.

e. Proses Akad Tabarru dan Pembayaran Dana Tabarru yang sudah ditetapkan oleh pihak BMT Mardhatillah Berkah karawang, Sesuai dengan jumlah Pembiayaan yang dilakukan oleh Anggota.

f. Anggota akan melaksanakan akad Tabarru dan pembiayaan di kantor BMT Mardhatillah Berkah Karawang.

Sehingga dapat digambarkan alur dalam Flow chart prosedur Mulai dari pengajuan pembiayaan sampai ke Pembayaran dan Tabarru yang akan di 


\section{EKSISBANK Vol. 4 No. 1 Juni 2020}

lakukan Oleh Pihak anggota dengan pihak BMT Mardhatillah Berkah Karawang sebagai berikut:

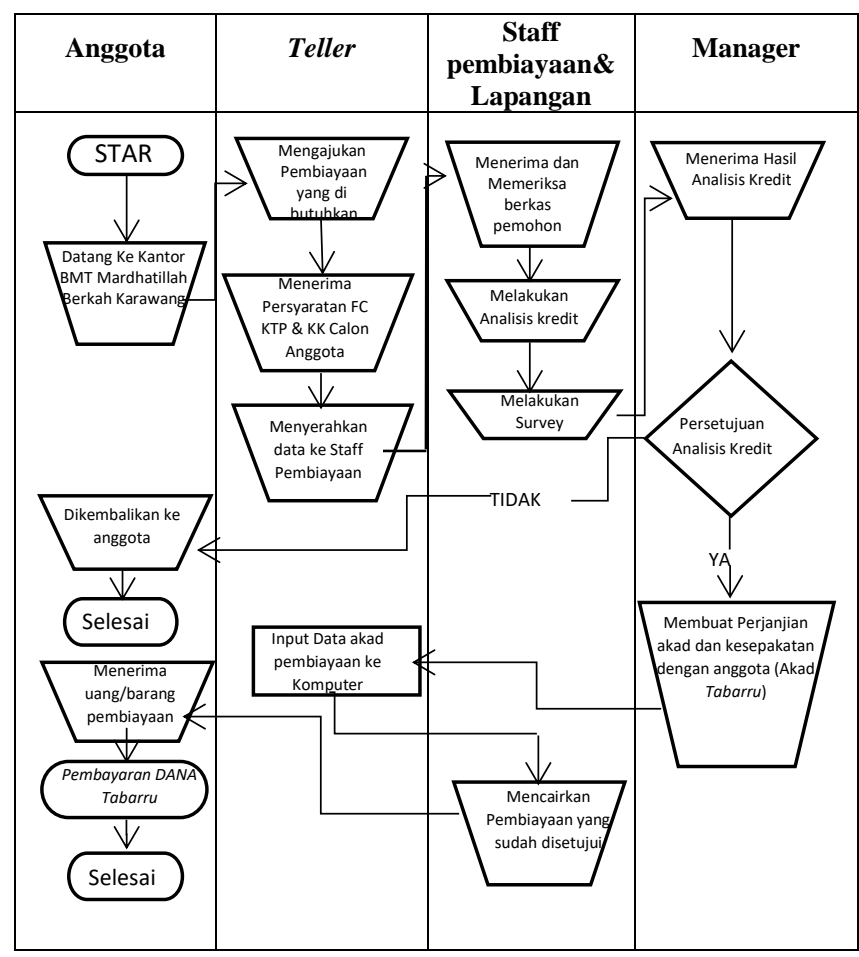

Anggota yang melakukan pembiayaan di BMT Mardhatillah Berkah, apapun jenis pembiayaan yang dilakukan, seperti Pembiayaan Murabahah, Mudharabah, Rahn, dan Qardhul Hasan, akan diwajibkan untuk membayar Dana Tabarru (Asuransi Jiwa Syariah) Adapun Sifat dari Dana Tabarru ini dana Hibah yang Di bayarkan oleh anggota BMT, Tujuan dari diwajibkannya anggota membayar Dana Tabarru (Asuransi Jiwa Syariah) hanya untuk melindungi setiap anggota dari resiko yang tidak diinginkan, karena manusia hanya bisa berencana dan Allah SWT yang menentukan Takdir kita.

BMT Mardhatillah Berkah merupakan lembaga yang menggunakan prinsip takaful (tolongmenolong) yang di implementasikan dengan cara saling menanggung. Apabila ada musibah, maka semua peserta asuransi syari'ah akan saling menanggung resiko. Dalam prakteknya dana yang dihibahkan oleh peserta (dana Tabarru) akan menjadi dana yang dipergunakan untuk pengajuan klaim peserta asuransi yang terkena musibah.

BMT Mardhatillah Berkah karawang dalam operasionalnya menggunakan skema sharing risk atau berbagi resiko. Berbagi resiko di lembaga seperti asuransi Syariah diawali dengan perjanjian dimana terdapat kesepakatan bahwa jika terjadi musibah kepada salah satu anggota yang melakukan pembiayaan, maka anggota lain akan saling tolong menolong dan saling menanggung. Maka dalam hal ini para peserta mengumpulkan dana dalam bentuk hibah yang terkumpul dalam dana Tabarru ketika ada anggota yang melakukan Pembiayaan, Bila mana terjadi musibah atau ada anggota yang meninggal, maka BMT Maradhatillah yang mewakili peserta untuk memberikan manfaat (klaim).

a. Mekanisme Pengelolaan Dana Tabarru di BMT Mardhatillah Berkah

Dana yang terkumpul dari pembayaran Tabarru yang dibayarkan anggota saat melakukan Pembiayaan akan disimpan di Rekening Khusus Tabarru. Sumber dana pembayaran klaim anggota diperoleh dari rekening Tabarru sepenuhnya, yaitu rekenig tolong menolong dari seluruh anggota yang sejak awal diakadkan dengan ikhlas oleh anggota untuk anggota yang meninggal dunia.

Berdasarkan hasil wawancara dengan bapak Abduloh selaku Manager BMT Mardhatillah Berkah Karawang, mengatakan bahwa setiap anggota yang melakukan Pembiayaan di BMT, Baik itu Pembiayaan Murabahah, Mudharabah, Dan Rahn, dan Qardhul Hasan akan ada Dana Tabarru yang harus dibayarkan pada saat Pencairan Pembiayaan dimana dana Tabarru ini akan digunakan untuk saling membantu atau saling menaggung apabila ada resiko meninggal diantara anggota BMT. Dana Tabarru yang sudah dibayarkan oleh Anggota nantinya akan dibayarkan kembali ke pihak asuransi yang sudah bekerja sama dengan Pihak BMT. Pihak Asuransi yang bekerja sama dengan BMT Mardhatillah Berkah yaitu PT Asuransi Syariah Keluarga Indonesia (Somad, 2019).

b. Kontribusi Dana Tabarru

Berdasarkan wawancara dengan bapak Abduloh selaku Manager BMT Mardhatillah Berkah Karawang, 26 September 2019 menyatakan bahwa besaran pembayaran dana Tabarru ketika melakukan pembiayaan, perhitungannya disesuaikan dengan Jumlah Pembiayaan anggota.

\section{Ilustrasi}

Nama Anggota

Alamat Anggota

: Nuryana

:Tanjungpura

Benteng, RT 004, RW 008, Desa. Tanjung Mekar, Kec. Karawang Barat, Kab. Karawang 
EKSISBANK Vol. 4 No. 1 Juni 2020

$\begin{array}{ll}\text { Tanggal Lahir } & : \text { 19 April } 1987 \\ \text { Umur } & : \text { 32 Tahun } \\ \text { Mulai Akad Perjanjian } & : \text { 8 April 2019 } \\ \text { Jangka Waktu } & : \text { 12 Bulan } \\ \text { Akhir Akad Perjanjian } & : \text { 8 April 2020 } \\ \text { Jenis Pembiayaan } & : \text { Murabahah } \\ \text { Jumlah Pembiayaan } & : \text { Rp 2.400.000,- } \\ \text { Kontribusi Tabarru } & : \text { Rp 2.400.000 x } \\ \text { 0.5\%= Rp 12.000 } & \end{array}$

Ilustrasi ini menjelaskan Bahwa Ada Anggota yang Bernama Nuryana Melakukan Pembiayaan Murabahah berupa pembelian 1 Unit HP di BMT Mardhatillah Berkah, adapun nominal pembiayaan yang dilakukan saduara Nuryana Sebesar Rp. 2.400.000,(Dua Juta Empat Ratus Ribu Rupiah) untuk perhitungan Dana Tabarru yang harus dibayarkan oleh sadura Nuryana sebesar Rp $2.400 .000 \times 0.5 \%=R p$ 12.000. Jadi Uang sebesar Rp 12.000,- (Dau Belas Ribu Rupiah) merupakan kontribusi Tabarru yang harus dibayarkan kepada pihak BMT Mardahtillah Berkah, lalu pihak BMT akan membayarkan kontribusi dana Tabarru yang sudah di bayarkan anggota kepada pihak asuransi yaitu PT Asuransi Syariah Keluarga Indonesia (PT ASYKI) untuk mendapatkan Polis Keikutsertaan Asuransi Jiwa Syariah (Somad, 2019).

Setiap pembayaran kontribusi dana Tabarru yang di setorkan akan langsung masuk ke rekening dana Tabarru. Dana Tabarru sendiri yaitu dana yang diniatkan oleh anggota dengan niat hibah untuk tolong menolong yang digunakan untuk perealisasian klaim anggota yang meninggal dunia.

c. Proses Klaim (Meninggal Dunia)

Menurut Fatwa Dewan Syariah Nasional (DSN) tentang pedoman Umum Asuransi Syariah, klaim adalah hak peserta asuransi yang wajib diberikan oleh perusahaan asuransi sesuai dengan kesepakatan dalam akad. Pada BMT Mardhatillah Berkah sumber pembiayaan klaim di kelola oleh Perusahaan Asuransi yang bekerja sama yaitu PT Asuransi Sayariah Keluarga Indonesia (ASyKi). Jadi jika ada anggota yang akan melakukan klaim/ meninggal dunia maka Pihak BMT Mardhatillah Berkah akan mempersiapkan dokumen persyaratan klaim, lalu dilaporakan dan dikirim ke pihak Asuransi.
Pada asuransi Syariah sumber pembiayaan klaim diperoleh dari Dana Tabarru yang sudah di bayarkan anggota yang melakukan pembiayaan di BMT Mardhatillah Berka. Asuransi dalam pandangan islam memahami makna berasuransi itu kegiatan yang dikerjakan dengan asas tolong menolong dengan landasan dan system yang berdasarkan syariat Islam, maka pengeluaran dana Tabarru benar-benar diniatkan dalam konteks ibadah semata mata hanya mengharapkan ridha Allah.

Sedangkan berdasarkan wawancara dengan Bapak Abdus Somad, S.Pd, selaku bagian Administrasi bahwa sumber pembayaran klaim diperoleh dari dana Tabarru yang sudah terkumpul dari anggota dan dibayarkan setiap anggota yang melakukan pembiayaan, namun pihak Asuransi PT ASyKi yang akan membayarkan klaim, dan di bayarkan ke Pihak BMT untuk menutupi sisa Kewajiban yang masih dimiliki oleh Anggota yang meninggal duni. Dana Tabarru yang sudah dibayarkan oleh anggota pada saaat melakukan pembiayaan dan anggota tidak melakukan proses Klaim/ Meninggal dunia maka sesuai kesepakatan tidak ada dana yang dikembalikan. Sesuai dengan kesepakatan diawal pada saat anggota melakukan Transaksi Akad Pembiayaan bahwa Dana Tabarru yang dibayarkan anggota merupakan Dana Hibah (Somad, 2019).

Adanya Dana Tabarru yang dibayarkan oleh anggota ketika melakukan pembiayaan, kepada pihak BMT Mardhatillah membuat anggota akan merasa tenang jika dikemudian hari ada musibah yang menyebabkan hingga meninggalnya anggota, karena takdir Allah kita tidak tau kapan akan datang seperti halnya kematian. Jika terjadi hal seperti itu otomatis anggota masih memiliki kewajiban yang harus dibayarkan, namun dengan anggota membayar dana Tabarru maka sisa dari kewajiban akan di Cover oleh dana Tabarru yang sudah terkumpul dari anggota yang melakukan pembiayaan di BMT Mardhatillah Berkah.

B. Penarapan Akad Tabarru di BMT Mardhatillah Berkah Karawang

Akad Tabarru' adalah akad perjanjian antara dua orang atau lebih tanpa mengharapkan imbalan dari pihak lain serta dilandasi dengan sikap tolong-menolong antar sesama dan 
tidak untuk mencari keuntungan (nonprofitoriented). Akad Tabarru' dalam asuransi yari'ah merupakan akad memindahkan kepemilikan harta/dana seseorang kepada orang lain melalui cara hibah.

Akad hibah merupakan salah satu akad penting dalam praktik kontemporer pada Lembaga Keuangan Syariah. Akad tersebut dirancangkan pada dua institusi lembaga keungan nonbank (Industri Keuangan Non Bank/ IKNB), yaitu perasuransian Syariah dan dana pensiun Syariah (Mubarak \& Hasanudin, 2018).

Menurut (Mubarak \& Hasanudin, 2018) mendefinisikan hibah secara terperinci :

Pertama, Kepindahan kepemilikan objek ('aqd yufid al-tamlik), yaitu akad hibah termasuk akad yang menyebabkan kepemilikan objeknya berpindah dari milik pemberi menjadi milik penerima. Kata 'aqd yufid al-tamlik menunjukan perbedaan antara akad hibah dan akad al-ariyah (pinjam barang), yaitu akad yang menyebabkan berpindahnya kepemilikan manfaat barang (sementara kepemilikan barangnya tidak berpindah) karena teori akad al-ariyah menghibahkan manfaat harta.

Kedua, Imbalan ( 'iwadh) kata ini menunjukan perbedaan akad hibah dan akad bisnis (mu'awadhat) yang ditandai adanya pertukaran antara barang (mutsman) dan harga (tsaman), sedangkan dalam akad ijarah terdapat pertukaran antara jasa /manfaat barang (manfa'ah) dan sewa/upah (ujrah). Akad hibah termasuk domain akad tabarru, dimana pemberi tidak memperoleh imbalan dari pihak penerima sebagai imbalan atas objek hibah yang diterimanya (sebagaimana teori pertukaran/al-mubadalah).

Ketiga, Waktu (halal-hayat), yaitu akad hibah dilakukan anta pemberi dan penerima pada saat pemberi masih hidup. Pernyataan tersebut untuk membedakan efektivitas (nafadz) akad hibah dan sekaligus membedakannya dengan akad wasiat. Hibah dan wasiat pada dasarnya sama yaitu akad yang membuat kepemilikan objeknya berpindah. Disamping itu, akad hibah dan akad wasiat memiliki ciri yang sama, yaitu pemberi tidak berhak menerima imbalan dari penerima, yang membedakan adalah efektivitasnya. Akad hibah adalah akad pemberian barang dari pemberi kepada penerima yang berlaku efektif pada saat pemberi hidup, sedangkan akad wasiat adalah akad pemberi barang dari pemberi kepada penerima yang berlaku efektif pada saaat pemberi meninggal.

Menurut (Karim, 2004) menuliskan pada hakikatnya akad Tabarru' adalah akad melakukan kebaikan yang mengharapkan balasan dari Allah SWT. semata. Itu sebabnya akad ini tidak bertujuan untuk mencari keuntungan komersil. Konsekuensi logisnya, bila akad Tabarru' dilakukan dengan mengambil keuntungan komersil, maka ia bukan lagi akad Tabarru', ia akan menjadi akad Tijarah. Bila ia ingin tetap menjadi akad Tabarru', maka ia tidak boleh mengambil manfaat (keuntungan komersil) dari akad Tabarru' tersebut. Tentu saja ia tidak berkewajiban menanggung biaya yang timbul dari pelaksanaan akad Tabarru'. Artinya ia boleh meminta pengganti biaya yang dikeluarkan salam melaksanakan akad Tabarru'.

Akad Tabarru' pada dasarnya diniatkan untuk tolong menolong, dan peserta asuransi memberikan dana Tabarru' tersebut dalam bentuk hibah. Hal tersebut telah sejalan dengan apa yang tercantum didalam Q.S. Al-Maidah (5)

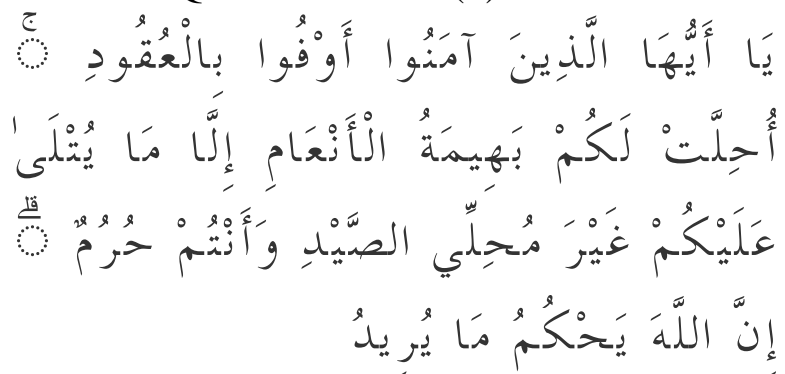

"Wahai orang-orang yang beriman! Penuhilah janji-janji. Hewan ternak dihalalkan bagimu, kecuali yang akan disebutkan kepadamu, dengan tidak menghalalkan berburu ketika kamu sedang berihram (haji atau umrah). Sesungguhnya Allah menetapkan hukum sesuai dengan yang Dia kehendaki” 


\section{EKSISBANK Vol. 4 No. 1 Juni 2020}

Dalam pelakasanaan kegiatan Pembiayaan di BMT Mardhatillah Berkah, akad atau transaksi Tabarru mulai diterapkan sejak terjadinya akad pembiayaan antara anggota dan BMT Mardhatillah Berkah. Dalam perjanjian akad tersebut di jelaskan perihal jumlah Tabarru yang harus dibayar, jangka waktu, dan porses jika terjadi klaim.

Penerapan akad Tabarru' di BMT Mardhatillah Berkah dipandang bersih dari mengandung unsur riba, maisir (perjudian), dan gharar (ketidak pastian). Sebab dalam pelaksanaan asuransi akad Tabarru' tersebut jumlah premi, jangka waktu, akad, serta sumber klaim semua jelas, serta atas kesepakadan kedua belah pihak (penanggung dan tertanggung). Selain itu saat dalam tanda tangan akad anggota yang melakukan pembiayaan di jelaskan perihal kegunaan Dana Tabarru yang di bayarkan oleh anggota. Dalam akad Tabarru', Anggota memberikan hibah yang akan digunakan untuk menolong Anggota BMT lainnya yang mengalami musibah atau kejadian diluar kehendak manusia, sehingga dana tersebut dipisahkan dengan dana lainnya. Dana Tabarru' sendiri digunakan apabila peserta yang mengajukan klaim mengalami kejaidan yang di luar dugaan atau musibah seperti meninggal dunia. Oleh karena itu dalam akad Tabarru' peserta asuransi yang memiliki dana Tabarru' memberikan dananya dengan ikhlas untuk tujuan tolong menolong sesama (Somad, 2019).

Dari hasil analisis penulis menyimpulkan bahwa pengelolaan dana Tabrru dan penerpan akad tabarru yang dilakukan oleh BMT Mardhatillah Berkah Karawang sesuai dengan kaidah dan prinsip Syariah.

\section{PENUTUP}

Setelah di lakukan kajian, analisis dan pembahasan pada bab sebelumnya atas permasalahan yang dirumuskan dan sesuai dengan tujuan penelitian. Dapat ditarik kesimpulan sebagai berikut:

a. Anggota yang melakukan Pembiayaan di BMT Mardhatillah Berkah Karawang akan diwajibkan untuk membayar Dana Tabarru dimana besarannya sebesar $0.5 \%$ dari jumlah Pokok Pembiayaan yang dilakukan pada saat Transaksi Akad Pembiayaan oleh anggota dengan Pihak BMT. Perihal Pengelola Pihak BMT hanya Mewakili pihak anggota untuk didaftarkan Asuransi Jiwa Syariah dalam produk Asuransi Pembiayaan dimana BMT Mardhatillah Berkah Karawang sudah bekerja sama PT Asuransi Syariah Keluarga Indonesia (AsyKi). Pengelolaan Dana Tabarru oleh pihak Asuransi, Uang yang sudah terkumpul dari dana Tabarru di simpan di rekening Khusus Tabarru.

b. BMT Mardhatillah Berkah Berkah Karawang menerapkan akad Tabarru' melalui cara hibah yang sejak dimulainya penandatanganan akad perjanjian hingga berakhirnya polis asuransi. Klaim atas dana Tabarru' di Kantor BMT Mardhatillah Berkah Karawang dapat dilakukan bila mana anggota yang melakukan Pembiayaan mengalami kejadian yang di luar dugaan atau diluar kehendak manusia seperti meninggal dunia. Ketentuan tersebut perlu diberlakukan dikarenakan pada asuransi Syariah sumber pembiayaan klaim akan diperoleh dari dana tabarru yang sudah terkumpul dari anggota yang melakukan pembiayaan.

B. Saran

Setelah Penulis melakukan penelitian terhadap Analisis Pengelolaan dana Tabarru (Asuransi Jiwa Syariah) Dalam produk pembiayaan di BMT Mardhatillah Berkah, penulis memberikan saran-saran yang kemungkinan jadi bahan masukan, adapun saran penulis sebagai berikut :

a. Dalam memberikan informasi terhadap calon peserta diharapkan informasi atas bagian akad Tabarru' lebih diperdalam, dikarenakan masih banyaknya kekurangan informasi atas akad Tabarru' sehingga dapat menumbuhkan lebih banyak lagi kepercayaan masyarakat terhadap asuransi Syariah yang sedang berkembang.

b. Akad tabarru sebaiknya dibuatkan akad tertulis yang menjelaskan besaran dana Tabarru yang harus dibayarkan anggota pada saat Pembiayaan diu BMT 
EKSISBANK Vol. 4 No. 1 Juni 2020

Mardahtillah Berkah, Prosedur Klaim jika ada anggota yang meninggal dan perlu terjadinya klaim. Memberikan Copian akad kepada anggota agar meminimalisir kesalahan komunikasi antara Anggota dan Pihak BMT Mardhatillah Berkah.

\section{DAFTAR PUSTAKA}

Arikunto, S. (2013). Prosedur Penelitian. Jakarta: PT. Asdi Mahasatya.

Buchari, A. (2009). Manajemen Bisnis Syariah. Bandung: Alfabeta.

Hasan, A. (2013). Manajemen Baitul Mal WaTamwil. Bandung: Pustaka Setia.

Karim, A. (2004). Bank Islam: Analisis Fiqih dan Keuangan. Jakarta: PT. Raja Grafindo Persada.

Kasmir. (2002). Dasar-dasar Perbankan. Jakarta: Raja Grafindo Persada.

Mubarak, J., \& Hasanudin. (2018). Fiqh Mu'amalah Maliyyah Akad Jual Beli. Bandung: Simbiosa Rekatama Media.

Somad, A. (2019). Pengelolaan Dana Tabarru (Asuransi Jiwa Syariah) dalam Produk Pembiyaaan di BMT Mardhatillah Berkah Karawang. Karawang: BMT Mardhatillah Berkah Karawang.

Sugiyono. (2016). Metodologi Penelitian Kuantitatif, Kualitatif dan R\&D. Bandung: Alfabeta.

Sugiyono. (2017). Metode Penelitian Kuantitatif, Kualitatif, dan $R \& D$. Bandung: Alfabeta.

Sula, M. S. (2004). Asuransi Syari'ah (Life And General): Konsep Dan Sistem Operasional. Jakarta: Gema Insani Press.

Suryani, \& Hendryadi. (2015). Metode Riset Kuantitatif. Jakarta: Kencana.

Syahatah, H. (2006). Asuransi dalam perspektif Syariah. Jakarta: Sinar Grafika Offset.

Tanjung, I. F. (2015). Penanganan pembiayaan bermasalah di BMT Amanah Mulia Magelang. 